\title{
$\begin{array}{ll}\text { Research Square } & \text { Preprints are preliminary reports that have not undergone peer review. } \\ \text { They should not be considered conclusive, used to inform clinical practice, }\end{array}$ or referenced by the media as validated information. \\ Evaluation and Discussion of Genetics Content in Museums
}

Abigail Howell

Arizona State University

Keighley Reisenauer ( $\boldsymbol{\nabla}$ Keighley_Reisenauer@baylor.edu )

Arizona State University https://orcid.org/0000-0003-0067-5684

Michelle Valkanas

California University of Pennsylvania

Katherine Carter

NCSE: National Council for Science and the Environment https://orcid.org/0000-0002-5440-5922

Research article

Keywords: Evaluation and Discussion, genetic technology, design ramifications

Posted Date: February 16th, 2021

DOI: https://doi.org/10.21203/rs.3.rs-200125/v1

License: (c) (1) This work is licensed under a Creative Commons Attribution 4.0 International License.

Read Full License 


\section{Evaluation and Discussion of Genetics Content in Museums}

A. A. Howell, K. N. Reisenauer*, M. M. Valkanas, and K. Carter. (2020) Evaluation and Discussion of Genetics Content in Museums. Manuscript in preparation.

*Corresponding Author, keighley_reisenauer@baylor.edu

$\begin{array}{ll}\text { Abstract } & 2\end{array}$

$\begin{array}{ll}\text { Introduction } & 2\end{array}$

$\begin{array}{ll}\text { Methods } & 4\end{array}$

Quantitative Analysis $\quad 4$

Data Sources and Search Criteria for Meta-Analysis 4

Inclusion and Exclusion Criteria for Meta-Analysis $\quad 4$

Explanatory Variables for Meta-Analysis $\quad 5$

Consideration of Bias $\quad 5$

Qualitative Data Collection and Analysis $\quad 5$

$\begin{array}{ll}\text { Results } & 6\end{array}$

Locations of Genetics Exhibits $\quad 6$

Interviews with Genetics-Containing Museum Institutions $\quad 7$

$\begin{array}{ll}\text { Approaches to Genetics } & 8\end{array}$

$\begin{array}{ll}\text { Discussion } & 10\end{array}$

Approaches to Genetics 11

Conclusion $\quad 14$

Declarations $\quad 15$

$\begin{array}{ll}\text { Availability of Data and Materials } & 15\end{array}$

Competing Interests $\quad 15$

$\begin{array}{ll}\text { Funding } & 15\end{array}$

$\begin{array}{ll}\text { Author Contributions } & 15\end{array}$

$\begin{array}{ll}\text { Acknowledgements } & 15\end{array}$

$\begin{array}{lr}\text { Figures and Supplemental } & 16\end{array}$

$\begin{array}{ll}\text { References } & 17\end{array}$ 


\section{Abstract}

Background: Genetics literacy is crucial for making informed personal decisions. With rapid advances in genetic technology, a foundational understanding of genetics is now more important than ever for meaningful engagement with questions surrounding health, privacy, and policy. However, genetic content engagement barriers, including geographic unavailability, lack of prior education, and misleading media narratives, can make it difficult to reach diverse populations. Furthermore, with growing mistrust in science and genetic information, interventions to improve genetics literacy, particularly to those beyond a $\mathrm{K}-12$ classroom, require an approach centered on building science trust and self-efficacy.

Results: For the meta-analysis, we found genetics content in 88 of the 691 museums queried, typically in science $(n=37)$ and natural history $(n=25)$ exhibits. While genetics content was present in 42 states, there were large portions of the country that were more than 150 miles away from any museum featuring genetics. We found a high concentration of genetics content in sponsored exhibits and a low concentration of content within children's museums, reinforcing narratives of genetic technology as product and genetics as difficult, respectively. In framing devices, museums fell into one of three categories. Museums with the meta-narrative "Genetics is Fun" focused on interactivity and volunteer facilitation, and emphasized specific inherited traits and genetics tools and technology. Museums highlighting the meta-narrative "Genetics is Relevant" highlighted DNA basics and health testing. Finally, museums with the meta-narrative "Genetics is Discovery" featured heavy use of fishbowl-style genetics labs, highly visible museum collections, and an emphasis on visitor participation in science research.

Conclusion: While each of these meta-narratives leads to high engagement with genetics topics, they also all lead to construction of different personal identities around these topics. For example, watching a diverse set of scientists work in a fishbowl lab broadens definitions of who can be a scientist, but active participation in a genetics experiment through volunteer facilitation builds science self-efficacy. Furthermore, narratives focusing on technological breakthroughs alone may inadvertently send a message that genetics is complex and impersonal. Exhibit creators should consider the design ramifications of each of these choices when creating an impactful genetics exhibit.

\section{Introduction}

Genetics literacy is becoming crucial for making informed personal decisions. With rapid advances in genetic technology, a foundational understanding of genetics is now important for meaningful 
engagement with questions surrounding health, privacy, and policy. Improving genetic literacy correlates with increases in trust in science and greater satisfaction with health decisions, and decreases in the prevalence of naturalistic fallacies about race $(1,2)$. Despite prevailing positive attitudes toward the use of genetics information, a high percentage of the general population lacks basic knowledge necessary to interpret disease risk and genetic susceptibility (3-5), to understand human evolutionary ancestry $(6,7)$, and to evaluate whether participation in genetic testing is an appropriate choice (8-10).

Though many state science education standards now include specific requirements for genetic literacy, many of these were implemented after 2010, leaving a large majority of current adults without access $(11,12)$. Adult genetic literacy is impeded primarily by access $(13,14)$, but also by lack of communication training among healthcare experts $(15,16)$ and perceived lack of self-efficacy to understand genetic information $(17,18)$. While a growth in availability of online resources led to greater access to genetics literature, they also have contributed to rapid dissemination of misinformation. Though traditional media sources may occasionally sensationalize, provoke alarm, or give equal weight to all ideas despite scientific consensus (19), social media can give a platform to, and algorithmically reinforce, misleading and false sources (20-22). The rise in misinformation contributes to the growing distrust in both journalism and science. Only $10 \%$ of the population currently has a high degree of trust in science journalism (23). This paradigm of rising mistrust and misinformation is particularly true with regard to potentially controversial science topics, including race and evolution, GMOs, and genetic testing $(22,24)$.

With growing mistrust in science and genetic information, interventions to improve genetics literacy, particularly to those beyond a $\mathrm{K}-12$ classroom, requires an approach that builds science trust and self-efficacy. Museums and other informal learning environments, such as libraries and nature centers, serve over 100 million visitors across the United States each year and are among the most trusted venues for science information (25). In addition, museums and other informal learning centers can foster discussion across multiple age cohorts (26-29) and provide a semi-structured, free=choice learning environment that allows the multi-directional bridging of knowledge between school and home $(30,31)$. While museums have a historical role in displaying, cataloging, and communicating knowledge, recent analyses have focused on these institutions's capacity for recontextualization and co-creation of knowledge (32-35).

Evidence suggests that increased exposure to genetic information in and of itself is not effective in driving visitors to informal learning environments to seek more information about genetics and to see themselves as part of the scientific process $(29,36-40)$. Instead, the design choices used to help visitors engage with genetics and evolution information dramatically impact visitor understanding, interest, and feelings of inclusion $(41,42)$. Many of these choices concern the subject and approach of the exhibit itself. For example, exhibits focusing on mechanisms such as transcription and translation are less well understood and often less appreciated than exhibits focusing on observable phenomena such as stratigraphy $(25,43,44)$. In addition, experiences that tell personal stories (45), take advantage of local connections $(46,47)$, and use unconventional learning approaches, such as video resources or gamification $(48,49)$, are more effective at driving understanding and establishing positive affinity with science.

Just as important as design and content choices to visitor interaction and understanding are the decisions about framing genetic information. While there have been no studies of the impacts of framing in genetics in museums, there have been a wealth of studies on the impacts of framing genetics within the broader conversation. Science communication around genetics frequently focuses on the novelty of new technologies, framing these developments as either making unprecedented breakthroughs or going too far towards playing God (50). Media coverage of these discoveries also perpetuate these narrow framing 
choices, particularly the "nature versus nurture debate," the metaphor of genetics as "unlocking life's code," and of genes coding directly for individual traits (51-55). De-emphasizing the "medical model" of genetics communication, focusing on polygenic rather than monogenic traits, and including developmental and phenotypic plasticity early in the curriculum all serve as effective means of avoiding these problematic metaphors and building inclusive frames of genetic knowledge in the formal education space $(1,2,56-58)$. While the implications of framing science in museums have been studied in exhibits on phylogeny (59), climate change (60), and anatomy (61), there has been little work done on the impact of the framing of genetics content in museums or more broadly, despite the growing realization of the importance of subtext and context in driving visitor understanding. By combining a meta-analytic approach and interviews with museum education professionals, we aim to understand the current physical distribution of genetics exhibits, analyze the impact of design decisions in such exhibits, and draw conclusions about the role both play in fostering genetics literacy and understanding. The goal of this research is to analyze emergent themes for effective hooks and learning goals for improving genetic literacy among adults and families and to understand key strategic areas for geographic and content expansion.

\section{Results}

\section{Locations of Genetics Exhibits}

A meta-analysis was performed to investigate the current landscape of genetics exhibits being offered in museums across the United States, in order to better understand the distribution of available genetics content and to identify large geographical gaps in availability. Based on our systematic review of genetic material in United States museums ( $n=691)$, we identified 88 publicly accessible institutions that have relevant exhibits, including 37 science museums (including 1 nature museum), 25 history museums, 4 medical, 3 children's museums, and 19 multi-subject museums (Figure 1a). To assess accessibility of genetic content, we computed the haversine (great-circle) distance from each museum to points on a rectangular grid covering the United States. For each point, we then calculated the distance to the nearest museum (Figure 1b). While some regions of the United States, particularly along the I-95 corridor, have an abundance of genetic information available in nearby museums, key regions of the Southwest and Midwest were lacking. There were eight states that lacked genetic content entirely: Idaho, Mississippi, New Jersey, Rhode Island, Vermont, West Virginia, Wisconsin, and Wyoming.

Further analysis was performed by analyzing museum accessibility based on location by setting a radius limit of 150 miles, the estimated maximum length of a day trip (Figure 1b). Most of the states that lacked genetic content of their own receive significant coverage from nearby states. But while Montana, Nebraska, Nevada, Texas, and South Dakota all have museums containing genetic content, there are large areas of these states without genetic content within 150 miles (Figure 1b).

\section{Interviews with Genetics-Containing Museum Institutions}

Twelve professionals from museums offered insights into the strategic decisions shaping current and recent genetics content in the United States (and Canada, which is culturally similar). Museums were 
located in the Midwest (Illinois, Missouri, Nebraska, Ohio), the South (Florida, Texas), the West (Colorado, Oregon, Utah, Washington), and Canada (Ontario). Interviewers AAH and KNR spoke to curators and exhibit designers, scientists, and outreach specialists. Some interviewees had backgrounds or worked actively in STEM; others in museum or exhibit design. Five of the twelve museums $(41.7 \%)$ were affiliated with universities.

During the interviews, many of the conversations were filled with energy and passion. Not all representatives were able to answer direct questions about intentional design decisions, learning goals, or evaluation. Overall, most of the interviewees described a workflow centered on the exhibit curatorial and design teams choosing what to talk about and how to talk about the desired topic, with the desired outcome or learning objectives being secondary. Of course, all conversations mentioned a desire for visitors to learn about the provided content, but not all had a clear vision of how to achieve that. Only three museums (Nebraska, IGB, Denver) reportedly centered museumgoer learning in their approach to exhibit implementation. All three that were scored as having learning goal-centered approaches also incorporated evaluation methods such as soliciting feedback from visitors (interviews, feedback slips, and polling) and tracking visitor/participant demographics.

The interviews were structured into "back-end" and "front-end" questions, focusing on the behind-the-scenes decisions that fueled the resulting exhibit product. When discussing how museum curators decided which topics to include in the exhibit, almost every museum (10 of 12) prioritized concepts deemed relevant to the visitors' lives such as health and genetic testing, trait inheritance and heritage, or genetics-based jobs. Many of the museums expressed a deeper desire for visitors to understand that genetics is not a new concept and that it is not removed from their daily life. One museum staff member summarized it well, saying, "Our idea was to help the public understand the contribution of current research that evolution research is an ongoing effort. It's not something that just, you know, came and went with Darwin." Building on this, two thirds of museums focused on genetics research or recent breakthroughs. However, there was not a correlation between the museums that were likely to have direct access to research via a university affiliation and a conversation about research in genetics. Not all university museums chose to focus on the importance of genetics research, and some museums without academic affiliations focused on the importance of genetics research nevertheless. The choices about how to convey the material varied as well. Eight of the twelve museums ensured that there were people available to help interpret and engage with the exhibit, either via researchers with labs integrated into the exhibit and/or via ambassadors or volunteers. Often, if museums implemented assisted interpretation, they also expressed learning goals stemming from conversations with local scientists (5 of 8 ). These goals did not follow a pattern, however. Outside of making genetics relevant to visitors, the most common goals for the exhibit were to produce an understanding about genetics facts (for example, the function of ribosomes, 5 of 12), or learning goals about scientists or research (for example, scientists are diverse, 5 of 12).

\section{Approaches to Genetics}

The results of k-means clustering suggests that there are three major approaches to genetic museum exhibitions, which may be described briefly as "Genetics is Fun," "Genetics is Relevant," and "Genetics is Discovery." 
Genetics is Fun: St. Louis Science Center (MO), Perot Museum of Nature and Science (TX), Science North (Ontario)

The category "Genetics is Fun" includes museums that expressed a desire for "visitors to have fun interacting with the exhibit" or included interactive elements/gamification as a key part of their exhibit design. The following are representative quotations from staff at museums in this category:

St. Louis Science Center: "Everybody wants to sort of like, touch, touch, touch and fun, find fun, and maybe I'll learn something along the way."

Perot Museum of Nature: "Fun becomes a big portion of what we want to make sure people are saying, so when we get word bubbles about your experience in the museum, usually fun ranks up there pretty high."

A core component of this approach is an emphasis on front-end evaluation, visitor feedback, and timing and tracking data. Understanding the experiential dimensions of the visit-how it makes visitors feel and how it might enrich their lives-is important to understanding the aspects of the exhibit the visitors look forward to, communicate with others, and cherish $(66,67)$. By better understanding visitor perspectives, museums are able to connect with visitors to encourage personal meaning-making and satisfying experiences.

Perot: We tend to focus less on our evaluation in terms of what did you learn in the hall, but more about what were you interested in and what things did you find interest in in the hall.

The qualitative analysis also shows that these types of museums focus primarily on the subjects of inheritance and genetic tools and technology in their exhibit topics and that they are also very volunteer-based in their exhibit interpretation. Science North distinctively utilizes its interactive elements and volunteers to teach inheritance through their object theater "Club Genome."

Science North: So it [object theater] is a theater that presents a show, and has physical objects that kind of explain the story like throughout the show, so as a visitor they're engaging with it and watching it.... Or for us at our science center, we call our staff blue coats, because we literally were like blue lab coats. So you know, visitors get to interact with blue coats and ask different questions.

Science North: [In] club genome. And we had, we had kind of like a, it was sort of like the little like disco inside. So the tables all lit up. And there were like flashing lights and colored lights...

Genetics is Relevant: University of Nebraska State Museum, Carl R. Woese Institute for Genomic Biology (IL), Arizona Science Center, Natural History Museum of Utah, Oregon Museum of Science and Industry

The central theme of the second category of museums was "Genetics Is Relevant," highlighting a variety of researchers and genetics topics in what were usually a part of a series of travelling exhibits.

Nebraska: But how do you make this story? You know, meaningful?... but you know, for the people who serve are in denial and think, oh, museums change people, and all my exhibits are so important. You know, that seems like oh, that's not very much, you know, but maybe it's a lot. 
Yeah. And maybe, that, you know, I've always believed that what museums do is part of a bigger project

IGB: translate genomics research and DNA research for the public to make it so that they feel comfortable making decisions about genomics in their everyday life

Health testing and DNA basics were two topics that were uniquely covered in this category. Studies show that educational interventions have been successful with respect to changing perceptions about direct-to-consumer genetics tests, indicating that museum exhibits focused on health testing are an effective strategy for increasing genetic literacy (48). The emphasis on DNA basics in these exhibits possibly stems from the adherence to state standards on genetics content reported by museum curators in interviews, which focuses primarily on conceptual knowledge components of genetic literacy rather than sociocultural or epistemic knowledge components.

Utah and OMSI stand out as a subcategory within this group. While they also emphasize research, travelling components, and building awareness in their design choices, their exhibit topics focus less on a variety of genetics concepts than on an overarching theme of a single topic. Museum staff interviewed described this as the "big idea" of the exhibit:

OMSI: And so we've decided to make a connection between science and this like cultural history. Genghis Khan, Mongol Empire thing. We're connecting them with genetics.

Genetics is Discovery: Florida Museum of Natural History, Burke Museum of Natural History and Culture (WA), Denver Museum of Nature \& Science (CO), Cincinnati Museum Center (OH)

The exhibits at museums in this category revolve around a "glassbox"-style genetics lab, where visitors can peer in and watch scientists at work. The primary goal of these types of exhibits is to showcase that museums actively conduct research using their collections and aren't simply a static "cabinet of curiosities". Visitor misconceptions about the purpose of museum collections threaten funding, which has already been declining since the economic crisis of 2008 (68).

Florida: For us, it also helps because we're a collections based museum. And we have 40 million objects in our collections. So people often say why do you need so many things? You know, why isn't one butterfly of a certain species enough? Why do you have to kill multiple butterflies of the same species and so the genetics lab gave us an opportunity to talk about, you know, how science is conducted?

Genetics research using museum collections is critical to advancing our understanding of biodiversity and how evolution shapes our world. Collections research also provides invaluable insights into how populations are changing, and even being threatened, in the face of climate change (69).. By showcasing visible research in the exhibit, these museums can combat visitor misconceptions about the role of collections in museums. Observing live researchers also increases visitor understanding of the practices in which genetic technology is applied and the process of science, which are important concepts in genetic literacy.

Some museums have taken this practice a step further by inviting museum visitors to participate in ongoing research. In the Denver Museum of Nature \& Science's "Genetics of Taste Lab," participants contribute phenotypic and genetic data to the lab's taste and genetics research studies. Through participation in this study, the visitors become familiar with the scientific process and can understand how 
the study relates to their own lives. Evaluation data from this study shows that guests both enjoy and value participating in authentic genetics research (70).

Denver: the goal is when they look in, and they see us working on actual science, that they see us wearing similar things, and they make the connection that they're scientists as well, and that there's a scientist to everybody.

\section{Discussion}

Barriers to accurate genetics content, particularly for those outside of traditional $\mathrm{K}-12$ schooling, include both physical location and feelings of exclusion in science. A meta-analysis was performed to understand types of museums offering genetics content nationwide. Of the 691 museums included in the study, only 88 of them had genetics content $(12.72 \%)$. The geographic distribution of museums carrying genetics content was analyzed to identify portions of the country that are lacking access to any genetics content. Large gaps were identified in the middle of the country (midwest and southwest), where informal science access to genetic content was lacking, leading to a reliance on other outlets to receive their genetic content. This often results in a reliance on internet content that is frequently inaccurate (71) and is often presented in a manner that is difficult to understand. Because genetics is often regarded as difficult, online content is often not conducive to learning and lacks the engagement strategies often utilized by museums such as personal stories (45) and local connections (46). The importance of having community access to science content is reinforced by research that shows that such content enhances learning through personal context (72). Because genetics is a constantly evolving field that is continuously being integrated into our daily lives, contextual learning is even more important when presenting genetics content.

Of the 88 genetics-containing museums in our study, close to half (36) were science museums. There were very few medical and children's museums that had genetics content. The low number of medical museums represented in the study can be attributed to the overall low number of medical museums that exist. But although there was a high number of children's museums included in the study ( $n=201$ ), only 3 of them were identified as offering genetic content. The Next Generation Science Standards suggest teaching genetics-related topics like inheritance, variation, and heredity as early as kindergarten, with Mendelian genetics being introduced in grade 3 (NGSS 3-LS3). In addition, teaching basic genetics concepts like inheritance are important foundational knowledge for more complex topics such as genomics and epigenetics (73). Despite this, the lack of genetics content in museums may be explained by a prevailing wisdom that genetics content is too complex for young children or a struggle to make genetics content sufficiently hands-on $(54,74)$. Lack of genetics context was particularly noticeable in children's exhibits centered on health, medical topics, and/or the human body. where genetics content could easily be incorporated. These exhibits were often sponsored by a local hospital or medical-related company and their content focused on doctors' offices, emergency rooms, anatomy, and/or fitness and nutrition. One explanation of this sponsorship driving messaging, where health and fitness are the focus as a result of healthcare sponsorship. While the direct messages in these exhibits are important and satisfy the needs of all stakeholders involved, the indirect messaging tells a potentially more harmful story by presenting health and fitness as unrelated to genetics. This can not only impair fundamental understanding of genetics but also lead to mistrust of genetics in healthcare (e.g. personalized medicine and gene therapy) if individuals come to believe that healthcare and genetics do not intersect. 
With the growing cost of building exhibits and the increasing pressure to maintain interactive and engaging exhibits, many museums are increasingly becoming dependent on corporate sponsorship. This has led not only to direct impacts on exhibit design, where sponsors are affecting the content, but also indirect impacts, where curators are adjusting and even self-censoring content based on their understanding of the views of the sponsor $(75,76)$. This could be one potential explanation for why exhibits sponsored by corporate health organizations focused on anatomy and health topics in the exhibit design (as discussed above), with little to no inclusion of even basic genetics content such as DNA and inheritance. Another possible explanation is that the museums prioritize the sponsor's needs on the website or advertising materials thus making it seem like genetics isn't covered.

Museums offering genetics content often had an affiliation with a college or university (26 of 88), where highlighting the research conducted at the affiliated institution resulted in the inclusion of genetics content. In these instances, the affiliation drove the direction towards genetics rather than away from it. However, the focus was often on highlighting the cutting-edge research, often unfinished science, the university was doing, rather than discussing current topics applicable to our everyday lives. Chittenden et al. 2004 describes the challenges of presenting "unfinished science" as it presents information that is incomplete and often is not portrayed in a way that draws clear association to the individuals (77). This was observed in some exhibits where the content was often displayed as a highlight, rather than an entire exhibit. There are some notable exceptions to this, such as the Cold Spring Harbor DNA Learning Centers and the Michigan State University Museum. Simply highlighting new and exciting genetic information without the needed context can lead to misinterpretation or omitting some of the information. However, Chittenden et al. 2004 argues for the importance of presenting "unfinished science," stating a need to pivot from the normal presentation of information to a more active involvement in the process of research. While the presentation of new technologies and "unfinished science" is important, the execution of this information is even more so. The incompleteness or uncertainty of the research being presented, as well as any possible controversy surrounding it, requires an engaging exhibit that allows the individual to see themselves in the science while actively participating in the research experience, rather than a passing-by excerpt of scientific advancements.

\section{Approaches to Genetics}

Within the existing genetics exhibits identified through the meta-analysis, approaches to displaying and framing the content differed in ways that affect ability to learn and how genetics is perceived $(41,42,78)$. Here we discuss how the design choices, messaging strategies, and learning goals of the emergent categories of genetics exhibits may each uniquely help to foster genetic literacy and understanding.

\section{"Doing Genetics"}

The museums within the category "Genetics is Fun" use an approach to presenting genetics where visitor enjoyment is the primary goal, which is accomplished mostly through interactive exhibits. Interactivity, through physical touch or "gamification," has become a key component in museums exhibits. Research on visitor learning in museums suggests that interactivity promotes engagement, understanding, and recall of exhibits (for a review, see (79)). Curators at the St. Louis Science Center described their replication and transcription exhibit, in which visitors cranked a handle to observe the process of "unzipping" the DNA and the nucleotides matching with their complementary base as "learning while doing". Design elements of challenge and play have also been found to increase visit duration and visitor 
understanding of science (80). Interactivity is further enhanced through staff or volunteers who guide audiences through demonstrations and presentations. Studies show that staffed exhibits have higher levels of attraction, holding power, and visitor engagement compared to unstaffed exhibits (81). Genetics exhibits with staffed interactive components allow visitors to experience genetics in a way that brings them into the process of discovery.

While increasing visitor enjoyment through fun, interactive exhibits is a high priority among exhibit designers (82), others argue that the role of museums is to move beyond entertainment in order to be effective as teaching tools (83). For genetics exhibits, there are a limited number of components that work well for interactivity (such as constructing a DNA model, completing Punnett squares, linking genes to behavior), and these interactives are often conceptually distant from one another. Though highly interactive exhibits can be successful at prolonged visitor retention, for genetics exhibits they largely communicate what genetics does, as opposed to what genetics is.

Moreover, museums can move beyond displaying information to fostering skills of scientific inquiry (such as asking questions and interpreting results) by inviting participants to engage in authentic genetics research, as in the Genetics of Taste Lab at the Denver Museum of Nature \& Science in the "Genetics is Discovery" category. Exhibits like these utilize the participation design principle, which asserts that visitor understanding is shaped by both physical experiences (84), which occur during sample collection, and dialogic interactivity (85), which occurs during study-driven informal and meaningful interactions with scientific staff and volunteers. Evaluation data from the Denver case study shows that visitors both value and enjoy contributing to research, and, that by actively participating in science, they feel more capable of understanding complex scientific concepts $(86,87)$. This increased confidence in visitor learning indicates a positive effect on visitor self-efficacy beliefs-their judgments of their ability to deal with or succeed in a certain situation (88) - with regard to genetics.

This approach of visitor participation in museum research is contrasted by the "glassbox" style of genetics exhibits also present within the "Genetics is Discovery" category, where visitors observe scientists conducting research inside a glass-walled laboratory. Studies show that these types of exhibits have a positive effect on visitors' perceptions of museums, challenging their assumptions that science is passive and that museums are home only to stale facts and dead things (89). Seeing scientists of diverse backgrounds in action can also work against commonly held assumptions about who is included in science (90). However, these types of exhibits also can leave visitors with an incomplete understanding of the research being conducted, because their interpretation is based only on what they observe. with no opportunities to address questions or misconceptions without an additional interpreter outside of the exhibit.

\section{"Unifying Genetics"}

Emergent themes that have been found to support science learning outside of physical interactivity include the immediate apprehendability of the exhibit, conceptual coherence, and consideration of the diversity of learners (83). Conceptual coherence is the communication of an abstract concept, theme, or model of science throughout many smaller exhibit pieces. Many museums within the "Genetics is Relevant" category communicated that they utilize a similar "big idea" method of exhibit design, where development is guided by "a one sentence statement that connects the visitor to the content and explains the relevance of the topic to them" (91). Conceptual coherence is part of the constructivist teaching perspective that learners need exposure not only to physical experiences but also to concepts and models (92). Conceptual coherence has been cited as a fundamental design tenet for creating an 
intrinsically motivating exhibit that is an effective teaching tool. The Oregon Museum of Science and Industry has used this concept to unite individual genetics topics like DNA basics, inheritance, genetic ancestry testing. and ethics through the "big idea" of Gengis Khan's genetic legacy.

Another technique used by exhibit designers to emphasize unifying narratives is cognitive scaffolding (93), in which questions, prompts, and other structured interactions act as cognitive supports for learners during an extended investigation (94), is another design principle used to make exhibit learning more effective by teaching inquiry skills. As supports (such as prompts and volunteer facilitators) gradually fade into the background during the activity, learners can continue autonomously $(95,96)$. The Burke Museum of Natural History and Culture explicitly identifies this as a design tactic employed there, where leading questions within each exhibit section prompt discussion and docents to guide and facilitate activities. Exhibits that employ scaffolding not only aim to strengthen inquiry skills but also provide various levels of engagement for visitors, resonating with the design practices of skimmability and layering for modeling information in three-dimensional space (82). By presenting information at various levels of depth (gallery headings, theme labels, object labels), visitors are able to explore in as much detail as they like and always leave feeling that they have learned a complete topic (82). These practices mitigate both the cognitive overload and the physical museum fatigue experienced by visitors $(97,98)$. Exhibits in the "Genetics is Relevant" category often supported science learning by using a compelling combination of expert and personal narratives within case studies in order to appeal to a diversity of learners. These narratives often not only discuss the "product" of genetic technology, but also the process of a particular technology's discovery. Researchers have noted that the narrative device is useful for stimulating personal reflection and discussion $(99,100)$. This may be in part due to the sense of similarity, grounding scientific concepts in ways that are more accessible to visitors (101). Because one of the goals of genetic literacy is to encourage decision-making following discussion and reflection, narratives are an invaluable tool of science communication. Further, case-based approaches are an ideal pedagogical model to highlight the real-world relevance of new theories (102). Additional frameworks that have been found to encourage evidence-based decision making and increase engagement with controversial socio-scientific exhibits are the principles of participatory design (85). Participatory exhibits are both social and visitor-determined, allowing visitors to become co-creators of meaning through their interactions with the exhibit. Additional studies support that visitor gains are increased when exhibits are structured and collaborative rather than spontaneous and individualized (103).

\section{"Framing Genetics"}

Generally, genetics research is portrayed in a positive light in the media, an image which is supported through the use of quotations from researchers, references to credible sources, appeals to human interest, and the use of particular words, metaphors and analogies (104). Similar techniques are evident within exhibits across categories of museums, most notably Science North's "Club Genome" as an extended, interactive analogy and the case studies of scientists at the University of Nebraska State Museum. While the overall image of genetic research is positive, the framing of science in the media has often been that of popularization and disseminating factual content rather than presenting the technology within a societal context (105). With respect to genetics, media framing focuses more specifically on the novelty of cutting-edge genetic technology, framing the discoveries as making breakthroughs or an attempt at playing God (50). Hansen (2006) argues that this type of binary narrative deters fruitful discussion surrounding the technology, as whatever cannot be classified as a natural phenomena is by default potentially immoral, wrong, or dangerous, and is therefore antithetical to the goals of genetic literacy regarding critical thinking and independent decision-making (106). Further, framing of genetics and medical advancements primarily focuses on genes coding directly for individual traits rather than the 
complexity of the gene-environment-trait interplay, which is also at odds with the nuanced perspective genetic literacy offers (51-55)..

\section{Conclusion}

Improving genetic literacy is critical to increasing trust in science, and results in greater satisfaction with health decisions and decreases in the prevalence of naturalistic fallacies about race $(1,2)$. While museums have been successfully communicating about genetics for almost a hundred years, they must continually evolve to reflect emerging technologies and the national discourse. Museums have experienced several paradigm shifts, from "cabinets of curiosities" through "experiential fact-based science centers" (the popularization paradigm) to the now-popular critical exhibits, which are largely issues-based and encourage visitors to actively engage with and consider socio-scientific issues from many perspectives (107). When applied to genetics, these frameworks promote decision-making, situate genetics technologies in social contexts, and encourage visitors to evaluate the certainty and uncertainty of genetic information and the (mis)representation of genetic knowledge in the media.

Our research sought to understand the barriers to genetics engagement, first by assessing the availability of genetics content across the United States and then by analyzing the framing choices used to convey genetics content in museums. Our meta-analysis revealed that despite the high trust placed in museums, many people still lack physical access to genetics content, particularly in the Midwest and in places where distrust in science is high. We identified three unique approaches used by exhibits, highlighting that genetics is fun, relevant, or based in discovery. While each of these frameworks can provide effective engagement, future genetics exhibits should consider design choices, messaging strategies, and learning goals, each with their own benefits and deficits, to develop exhibits that both inform and challenge in engaging ways to ultimately increase visitors' genetic literacy.

\section{Methods}

\section{Quantitative Analysis}

\section{Data Sources and Search Criteria for Meta-Analysis}

The guidelines for Preferred Reporting Items for Systematic Review and Meta-analysis Protocols (PRISMA-P) were followed when applicable (62). Museums were selected through two individual search methods: 1) AAH used the Google search engine to search for the terms "[STATE]" for each of the fifty U.S. states, "genetics", and "exhibit"; 2) MMV used the online encyclopedia Wikipedia and searched the phrase "List of museums in [STATE]" for each of the fifty U.S. states. All museums meeting initial inclusion criteria were then analyzed further by visiting their individual websites and reviewing their current exhibits. Additionally, an advanced Google search (https://www.google.com/advanced search) was performed using genetic terminology (see "Explanatory Variables for Meta-Analysis" below) restricted to the museum website. This was completed by inserting all genetic terminologies in the "Find pages with any of these" section and inserting museum website homepage into the "Narrow your search by site or domain" section. Search results that matched exhibit design were recorded, while online supplemental material for classrooms and at home activities were not included. Details of the electronic search strategy are provided in Figure 1. 


\section{Inclusion and Exclusion Criteria for Meta-Analysis}

For methodological consistency, inclusion and exclusion criteria were compiled. For museums with different locations meeting the inclusion criteria , the locations were analyzed separately.

The inclusion eligibility criteria were as follows:

- located within one of the 50 U.S. states

- characterized based on content as one of the following types of museum:

$\begin{array}{ll}\circ & \text { science } \\ \circ & \text { history } \\ \circ & \text { children } \\ \circ & \text { nature } \\ \circ & \text { medical } \\ \circ & \text { multiple (2+ of the above categories) }\end{array}$

- currently featuring exhibit(s) with a genetic component as described under Explanatory Variables for Meta-analysis below.

The exclusion criteria were as follows:

- no longer in business as of June 2020

- characterized as the type local history

- lacked an official website

\section{Explanatory Variables for Meta-Analysis}

To determine genetic components of an exhibit, we searched museum websites for genetic terminology as defined by Elston et al. 2012 (63), which included the following terms gene, allele, locus, genotype, phenotype, dominant, recessive, codominant, polymorphism, mutation, complex trait, multifactorial, polygenic, monogenic, and haplotype. Broader terms also included genetics, DNA, chromosome, trait, heritability, pedigree, and Darwinism.

List of museums included in the meta-analysis and their category type are reported in the Appendix.

\section{Consideration of Bias}

For the meta-analysis, quality and amount of online content could have been a biasing factor in determining inclusion in our study. For this reason, it is possible that we have oversampled large museums or those with a prominent online strategy or that we have undersampled small museums that may have some genetic component. To avoid bias caused by search engine optimization, we used a comprehensive list of museums by state found on Wikipedia and then manually searched each museum's website. Additionally, to avoid bias caused by website design, both keyword searches and manual examination of exhibit photographs were used. 


\section{Qualitative Data Collection and Analysis}

$\mathrm{AAH}$ and KNR conducted semistructured interviews with museum education professionals at twelve institutions and museums to explore the learning goals and hooks of genetics exhibits. The museums were:

- Arizona Science Center

- Burke Museum

- Cincinnati Museum

- Denver Museum of Nature \& Science

- Florida Museum of Natural History

- Institute of Genomic Biology (IGB)

- Nebraska State Museum

- Oregon Museum of Science and Industry

- Perot Museum

- Science North (in Sudbury, Ontario)

- St. Louis Science Center

- Utah Natural History Museum

The semistructured interview format allowed the interviewers to address both predetermined and emergent topics (64). Audio recordings of interviews were transcribed verbatim using the software Otter.ai (http://otter.ai). Researchers used a structural codebook framework (65) to iteratively analyze the transcripts for emergent themes related to exhibit hall contents, exhibit topics, interpretation, design approach, learning goals development, and learning goal topics, hooks, and evaluation. The multistage coding process began with both researchers individually coding two interview transcripts from different timepoints, with an interobserver error of around $20 \%$. In the second iteration of the codebook. researchers removed "exhibit hall contents" and added an additional criterion of "motivation" (i.e. the primary reason the museum/institution created a genetics exhibit). The second iteration also included definitions and text examples from interviews to provide further guidance and specificity. The revised codebook was used to code two different transcripts, with an interobserver error of $10 \%$. This final codebook was then used to code the remaining ten transcripts. All subsequent qualitative analysis was conducted with the software package factoextra. The codings for qualitative analysis were analyzed for emergent themes using k-means clustering analysis, with a random partition initialization metric and iterated over (1 to $\mathrm{n}-1$ ) means using the kmeans function in $\mathrm{R}$.

\section{Declarations}

\section{Availability of Data and Materials}

All de-identified results, protocols, and resources are reported herein or in supplemental information.

\section{Competing Interests}

The authors declare that they have no competing interests 


\section{Funding}

This research was supported by The National Center for Science Education.

\section{Author Contributions}

$\mathrm{AH}$ : study design, data collection, analysis, writing of manuscript. KR: study design, data collection, writing of manuscript. MV: study design, data collection, analysis, writing of manuscript. KC: study design, analysis, writing of manuscript. All authors read and approved the final manuscript.

\section{Acknowledgements}

We thank Glenn Branch for comments on the manuscript

\section{References}

1. Donovan BM, Semmens R, Keck P, Brimhall E, Busch KC, Weindling M, et al. Toward a more humane genetics education: Learning about the social and quantitative complexities of human genetic variation research could reduce racial bias in adolescent and adult populations. Sci Educ. 2019;103(3):529-60.

2. Donovan BM, Weindling M, Salazar B, Duncan A, Stuhlsatz M, Keck P. Genomics literacy matters: Supporting the development of genomics literacy through genetics education could reduce the prevalence of genetic essentialism. J Res Sci Teach. 2020 Oct 6;n/a(n/a):31.

3. Abrams LR, Koehly LM, Hooker GW, Paquin RS, Capella JN, McBride CM. Media Exposure and Genetic Literacy Skills to Evaluate Angelina Jolie's Decision for Prophylactic Mastectomy. Public Health Genomics. 2016;19(5):282-9.

4. Scheuner MT, Sieverding P, Shekelle PG. Delivery of Genomic Medicine for Common Chronic Adult Diseases: A Systematic Review. JAMA. 2008 Mar 19;299(11):1320.

5. Smerecnik CMR, Mesters I, de Vries NK, de Vries H. Educating the general public about multifactorial genetic disease: applying a theory-based framework to understand current public knowledge. Genet Med. 2008 Apr;10(4):251-8.

6. Bobkowski PS, Watson JC, Aromona OO. A Little Bit of That from One of Your Grandparents: Interpreting Others' Direct-to-Consumer Genetic Ancestry Results. Genealogy. 2020 Jun;4(2):54.

7. Roth WD, Yaylacı Ş, Jaffe K, Richardson L. Do genetic ancestry tests increase racial essentialism? Findings from a randomized controlled trial. PLoS ONE [Internet]. 2020 Jan 29 [cited 2020 Aug 13];15(1). Available from: https://www.ncbi.nlm.nih.gov/pmc/articles/PMC6988910/

8. Chen L-S, Goodson P. Public Health Genomics knowledge and attitudes: A survey of public health educators in the United States. Genet Med. 2007 Aug;9(8):496-503.

9. Ciske DJ, Haavisto A, Laxova A, Rock LZ, Farrell PM. Genetic counseling and neonatal screening for cystic fibrosis: an assessment of the communication process. Pediatrics. 2001 Apr;107(4):699-705.

10. Sauven P. Guidelines for the management of women at increased familial risk of breast cancer. Eur J Cancer. 2004 Mar 1;40(5):653-65.

11. Dougherty MJ, Pleasants C, Solow L, Wong A, Zhang H. A Comprehensive Analysis of High School 
Genetics Standards: Are States Keeping Pace with Modern Genetics? CBE Life Sci Educ. 2011;10(3):318-27.

12. Lontok KS, Zhang H, Dougherty MJ. Assessing the Genetics Content in the Next Generation Science Standards. PLOS ONE. 2015 Jul 29;10(7):e0132742.

13. Chapman R. Genetic Literacy And Attitudes Survey (Iglas): International Population-Wide Assessment Instrument. In 2017 [cited 2020 Aug 13]. p. 45-66. Available from: http://www.futureacademy.org.uk/files/images/upload/ICPE2017F6.pdf

14. Lanie AD, Jayaratne TE, Sheldon JP, Kardia SLR, Anderson ES, Feldbaum M, et al. Exploring the public understanding of basic genetic concepts. J Genet Couns. 2004 Aug;13(4):305-20.

15. Blazer KR, Macdonald DJ, Culver JO, Huizenga CR, Morgan RJ, Uman GC, et al. Personalized cancer genetics training for personalized medicine: improving community-based healthcare through a genetically literate workforce. Genet Med Off J Am Coll Med Genet. 2011 Sep;13(9):832-40.

16. Marks NJ. Public Understanding of Genetics: The Deficit Model. In: John Wiley \& Sons Ltd, editor. eLS [Internet]. Chichester, UK: John Wiley \& Sons, Ltd; 2016 [cited 2020 Aug 13]. p. 1-5. Available from: http://doi.wiley.com/10.1002/9780470015902.a0005862.pub3

17. Carere DA, Kraft P, Kaphingst KA, Roberts JS, Green RC. Consumers report lower confidence in their genetics knowledge following direct-to-consumer personal genomic testing. Genet Med. 2016 Jan;18(1):65-72.

18. Kaphingst KA, Blanchard M, Milam L, Pokharel M, Elrick A, Goodman MS. Relationships Between Health Literacy and Genomics-Related Knowledge, Self-Efficacy, Perceived Importance, and Communication in a Medically Underserved Population. J Health Commun. 2016;21 Suppl 1:58-68.

19. Corley EA, Scheufele DA. Outreach gone wrong? When we talk nano to the public, we are leaving behind key audiences. The Scientist. 2010;24(1):22.

20. Chou W-YS, Oh A, Klein WMP. Addressing Health-Related Misinformation on Social Media. JAMA. 2018 Dec 18;320(23):2417-8.

21. Vicario MD, Bessi A, Zollo F, Petroni F, Scala A, Caldarelli G, et al. The spreading of misinformation online. Proc Natl Acad Sci. 2016 Jan 19;113(3):554-9.

22. Wang Y, McKee M, Torbica A, Stuckler D. Systematic Literature Review on the Spread of Health-related Misinformation on Social Media. Soc Sci Med. 2019 Nov;240:112552.

23. National Science Foundation. Science and Engineering Indicators 2018. In Alexandria, VA: National Science Board; 2018. p. 1060. Available from: https://www.nsf.gov/statistics/2018/nsb20181/assets/nsb20181.pdf

24. Allen CG, Andersen B, Khoury MJ, Roberts MC. Current Social Media Conversations about Genetics and Genomics in Health: A Twitter-Based Analysis. Public Health Genomics. 2018;21(1-2):93-9.

25. MacFadden BJ. Evolution, museums and society. Trends Ecol Evol. 2008 Nov;23(11):589-91.

26. Diamond J. The Behavior of Family Groups in Science Museums. Curator Mus J. 1986;29(2):139-54.

27. Ellenbogen K. Museums in Family Life: An Ethnographic Case Study. In 2003.

28. Duensing S. Culture Matters: Informal Science Centers and Cultural Contexts. Counterpoints. 2006;249:183-202.

29. Zimmerman HT, Reeve S, Bell P. Family sense-making practices in science center conversations. Sci Educ. 2010;94(3):478-505.

30. Crowley KD, Schunn CD, Okada T, editors. Designing for science: implications from everyday, classroom, and professional settings. Mahwah, N.J: Lawrence Erlbaum Associates; 2001. 498 p.

31. Miller J, Barrington T. The Acquisition and Retention of Scientific Information. J Commun. 2006 Feb 7;31:178-89.

32. Antón C, Camarero C, Garrido M-J. Exploring the experience value of museum visitors as a co-creation process. Curr Issues Tour. 2018 Aug 13;21(12):1406-25.

33. Taffe S, Kelly M. Exchanging Expertise across Cultures and Time: Participatory Design Approaches for Creating Community Museums. Des J. 2020 Sep 2;23(5):715-34.

34. Henning M. New Media. In: A Companion to Museum Studies [Internet]. John Wiley \& Sons, Ltd; 2006 [cited 2021 Jan 22]. p. 302-18. Available from:

https://onlinelibrary.wiley.com/doi/abs/10.1002/9780470996836.ch18 
35. Rock J, McGuire M, Rogers A. Multidisciplinary Perspectives on Co-creation. Sci Commun. 2018 Aug 1;40(4):541-52.

36. Kelly LJ. The Interrelationships Between Adult Museum Visitors' Learning Identities and Their Museum Experiences [Internet] [Ph.D.]. [Sydney, Australia]: University of Technology, Sydney; 2007 [cited 2021 Jan 22]. Available from:

https://media.australian.museum/media/dd/Uploads/Documents/9316/Paper\%20CECA\%202007.58 e735c.pdf

37. Wilde M, Urhahne D. Museum learning: a study of motivation and learning achievement. J Biol Educ. 2008 Mar;42(2):78-83.

38. Holmes JA. Informal learning: Student achievement and motivation in science through museum-based learning. Learn Environ Res. 2011 Oct 1;14(3):263-77.

39. Hinojosa L, Swanson RD, Polman JL. Community Science Identity: Becoming Community Scientists in a Museum-based Genetics of Taste Program. 2018 Jul [cited 2021 Jan 22]; Available from: https://repository.isls.org//handle/1/700

40. Hinojosa L. Identity Development, Participation, and Equity in Museum Community Science Programs [Internet] [Ph.D.]. [United States -- Colorado]: University of Colorado at Boulder; 2020 [cited 2021 Jan 22]. Available from: http://search.proquest.com/docview/2407321687/abstract/EC25C6B5601C4A6APQ/1

41. Dunbar K, Klahr D. Developmental Differences in Scientific Discovery Processes. In: Developmental Differences in Scientific Discovery Processes [Internet]. 1st ed. Psychology Press; 1989 [cited 2021 Jan 22]. p. 36. Available from:

https://www.taylorfrancis.com/chapters/developmental-differences-scientific-discovery-processes-ke vin-dunbar-david-klahr/10.4324/9780203761618-9

42. Hammer D, Elby A, Scherr R, Redish E. Resources , framing , and transfer p . 1 Resources , framing , and transfer [Internet]. 2004 [cited 2021 Jan 22]. Available from: /paper/Resources-\%2C-framing-\%2C-and-transfer-p-.-1-Resources-Hammer-Elby/47d421d1e3ffb4 2a57e3bae96c3d5a5b6e8fd4a1

43. Evans E, Spiegel A, Gram W, Frazier B, Tare M, Thompson S, et al. A Conceptual Guide to Natural History Museum Visitors' Understanding of Evolution. Educ Psychol Pap Publ [Internet]. 2010 Jan 1; Available from: https://digitalcommons.unl.edu/edpsychpapers/196

44. Tison Povis K. Designing for Family Learning in Museums: How Framing, Joint Attention, Conversation, and Togetherness are at Play [Internet] [Ph.D.]. [Pennsylvania]: University of Pittsburgh ETD; 2017 [cited 2021 Jan 22]. Available from: http://d-scholarship.pitt.edu/30640/

45. Bransford J, National Research Council (U.S.), National Research Council (U.S.), editors. How people learn: brain, mind, experience, and school. Expanded ed. Washington, D.C: National Academy Press; 2000. 374 p.

46. Bonham VL, Citrin T, Modell SM, Franklin TH, Bleicher EWB, Fleck LM. Community-Based Dialogue: Engaging Communities of Color in the United States' Genetics Policy Conversation. J Health Polit Policy Law. 2009 Jun;34(3):325-59.

47. UMichCGFFinalReport.pdf [Internet]. [cited 2020 Aug 13]. Available from: https://www.genome.gov/Pages/About/OD/ECIB/FHDemonstrationProjectReports/UMichCGFFinalR eport.pdf

48. Pearson YE, Liu-Thompkins Y. Consuming Direct-to-Consumer Genetic Tests: The Role of Genetic Literacy and Knowledge Calibration. J Public Policy Mark. 2012 Apr;31(1):42-57.

49. Sabatello M, Chen Y, Sanderson SC, Chung WK, Appelbaum PS. Increasing genomic literacy among adolescents. Genet Med. 2019 Apr;21(4):994-1000.

50. Hellsten IR, Nerlich B. Genetics and Genomics The Politics and Ethics of Metaphorical Framing. In: Handbook of Public Communication of Science and Technology [Internet]. Routledge; 2008 [cited 2021 Jan 22]. p. 93-109. Available from: https://research.vu.nl/en/publications/genetics-and-genomics-the-politics-and-ethics-of-metaphorical -fra

51. Pramling N, Säljö R. Scientific Knowledge, Popularisation, and the Use of Metaphors: Modern genetics in popular science magazines. Scand J Educ Res - SCAND J EDUC RES. 2007 Jul 1;51:275-95. 
52. Kampourakis K. The Bad Use of Metaphors and the Use of Bad Metaphors. Sci Educ. 2016 Dec 1;25(9):947-9.

53. Gallop L, Chapman R, Selita F, Kovas Y. Effects of Education and Media Framing on Genetic Knowledge and Attitudes. Eur Proc Soc Behav Sci EpSBS. 2017 Dec 12;33(13):121-41.

54. Stern F, Kampourakis K. Teaching for genetics literacy in the post-genomic era. Stud Sci Educ. 2017 Jul 3;53(2):193-225.

55. Zolyan ST. Does a Ribosome Really Read? On the Cognitive Roots and Heuristic Value of Linguistic Metaphors in Molecular Genetics. Part 1. Russ J Philos Sci. 2020 May 27;63(1):101-15.

56. Donovan BM. Framing the Genetics Curriculum for Social Justice: An Experimental Exploration of How the Biology Curriculum Influences Beliefs About Racial Difference. Sci Educ. 2016;100(3):586-616.

57. Jamieson A, Radick G. Genetic Determinism in the Genetics Curriculum. Sci Educ. 2017 Dec 1;26(10):1261-90.

58. Hales KG. Signaling Inclusivity in Undergraduate Biology Courses through Deliberate Framing of Genetics Topics Relevant to Gender Identity, Disability, and Race. CBE-Life Sci Educ. 2020 May 1;19(2):es2.

59. Stephens S. From Tree to Map: Using Cognitive Learning Theory to Suggest Alternative Ways to Visualize Macroevolution. Evol Educ Outreach. 2012 Dec;5(4):603-18.

60. Kirk J. Framing Climate Change : The climate scepticist framing of climate change by the National Museum of Natural History, Washington, DC. 2017 [cited 2021 Jan 22]; Available from: http://lup.lub.lu.se/student-papers/record/8906969

61. Pedretti E, lannini AMN, Nazir J. Exploring Controversy in Science Museums: Non-visitors and the Body Worlds Exhibits. Can J Sci Math Technol Educ. 2018 Jun 1;18(2):98-113.

62. Moher D, Shamseer L, Clarke M, Ghersi D, Liberati A, Petticrew M, et al. Preferred reporting items for systematic review and meta-analysis protocols (PRISMA-P) 2015 statement. Syst Rev. 2015 Jan 1;4(1):1.

63. Elston RC, Satagopan JM, Sun S. Genetic terminology. Methods Mol Biol Clifton NJ. 2012;850:1-9.

64. Lofland J, Lofland J, editors. Analyzing social settings: a guide to qualitative observation and analysis. 4th ed. Belmont, CA: Wadsworth/Thomson Learning; 2006. 282 p.

65. Ryan GW, Bernard HR. Techniques to Identify Themes. Field Methods. 2003 Feb 1;15(1):85-109.

66. Ritchie JRB, Hudson S. Understanding and meeting the challenges of consumer/tourist experience research. Int J Tour Res. 2009;11(2):111-26.

67. Schmitt-Scheersoi A, Vogt H, Naumann C. The development of situation interests in an informal learning environment-a visitor evaluation study in an educational exhibition on individuality. In 2002. p. 22-6.

68. Kemp C. Museums: The endangered dead. Nat News. 2015 Feb 19;518(7539):292.

69. Wandeler P, Hoeck PEA, Keller LF. Back to the future: museum specimens in population genetics. Trends Ecol Evol. 2007 Dec;22(12):634-42.

70. Nuessle TM, McNamara PA, Garneau NL. Using Museum Guests as Crowdsourced Participants in Human Subject Research. Curator Mus J. 2020 Jul;63(3):407-29.

71. Kortum P, Edwards C, Richards-Kortum R. The Impact of Inaccurate Internet Health Information in a Secondary School Learning Environment. J Med Internet Res [Internet]. 2008 Jun 30 [cited 2021 Jan 22];10(2). Available from: https://www.ncbi.nlm.nih.gov/pmc/articles/PMC2483927/

72. Bamberger $Y$, Tal T. Learning in a personal context: Levels of choice in a free choice learning environment in science and natural history museum. Sci Educ. 2007 Jan 1;91:75-95.

73. Ibourk A, Williams M, Heidemann M. Learning About Genetics in an Elementary Classroom Using a Web-Based Inquiry Science Environment (WISE) Unit. In 2017.

74. Schmiemann P, Nehm RH, Tornabene RE. Assessment of Genetics Understanding. Sci Educ. 2017 Dec 1;26(10):1161-91.

75. Gray G, Kendzia V. Organizational Self-Censorship: Corporate Sponsorship, Nonprofit Funding, and the Educational Experience [Internet]. Rochester, NY: Social Science Research Network; 2009 [cited 2021 Jan 22]. Report No.: ID 2237608. Available from: https://papers.ssrn.com/abstract=2237608

76. Davidsson E, Sørensen H. Sponsorship and exhibitions at Nordic science centres and museums. 
Mus Manag Curatorship. 2010 Dec 1;25:345-60.

77. Chittenden D, Farmelo G, Lewenstein BV. Creating Connections: Museums and the Public Understanding of Current Research. Rowman Altamira; 2004. 410 p.

78. Nisbet MC, Mooney C. Framing Science. Science. 2007 Apr 6;316(5821):56-56.

79. Schneider B. Measuring Results: Gaining Insight on Behavior Change Strategies and Evaluation Methods from Environmental Education, Museum, Health, and Social Marketing Programs. Coevolution Institute; 2003. 146 p.

80. Perry D. What Makes Learning Fun? Principles for the Design of Intrinsically Motivation Museum Exhibits. 2012.

81. Boisvert DL, Slez BJ. The relationship between exhibit characteristics and learning-associated behaviors in a science museum discovery space. Sci Educ. 1995;79(5):503-18.

82. Carliner S. Modeling Information for Three-dimensional Space: Lessons Learned from Museum Exhibit Design. Tech Commun. 2003 Nov 1;50:554-70.

83. Allen S. Designs for learning: Studying science museum exhibits that do more than entertain. Sci Educ. 2004 Jul;88(S1):S17-33.

84. Alt MB, Shaw KM. Characteristics of ideal museum exhibits. Br J Psychol. 1984;75(1):25-36.

85. Simon N. The Participatory Museum. First Edition. Santa Cruz, California: Museum 2.0; 2010. 388 p.

86. Burcham ZM, Garneau NL, Comstock SS, Tucker RM, Knight R, Metcalf JL. Patterns of Oral Microbiota Diversity in Adults and Children: A Crowdsourced Population Study. Sci Rep. 2020 Feb 7;10(1):2133.

87. Garneau NL, Nuessle TM, Mendelsberg BJ, Shepard S, Tucker RM. Sweet liker status in children and adults: Consequences for beverage intake in adults. Food Qual Prefer. 2018 Apr 1;65:175-80.

88. Bandura A. Self-efficacy: Toward a unifying theory of behavioral change. Psychol Rev. 1977;84(2):191-215.

89. Wylie CD. Glass-boxing Science: Laboratory Work on Display in Museums. Sci Technol Hum Values. 2020 Jul 1;45(4):618-35.

90. Miller DI, Nolla KM, Eagly AH, Uttal DH. The Development of Children's Gender-Science Stereotypes: A Meta-analysis of 5 Decades of U.S. Draw-A-Scientist Studies. Child Dev. 2018 Nov;89(6):1943-55.

91. Pekarik A. Developing Interactive Exhibitions at the Smithsonian. :35.

92. Driver R, Asoko H, Leach J, Scott P, Mortimer E. Constructing Scientific Knowledge in the Classroom. Educ Res. 1994 Oct 1;23(7):5-12.

93. Wood D. Scaffolding, Contingent Tutoring and Computer-supported Learning. Int J Artif Intell Educ. 2001 Jan 1;12.

94. Samarapungavan $A$, Mantzicopoulos $P$, Patrick $H$. Learning science through inquiry in kindergarten. Sci Educ. 2008;92(5):868-908.

95. Collins A, Brown J, Newman S. Cognitive Apprenticeship: Teaching the Crafts of Reading, Writing, and Mathematics. In 2018. p. 453-94.

96. Vygotsky LS. Mind in Society: Development of Higher Psychological Processes [Internet]. Cole M, Jolm-Steiner V, Scribner S, Souberman E, editors. Harvard University Press; 1980 [cited 2021 Jan 22]. Available from: http://www.jstor.org/stable/10.2307/j.ctvjf9vz4

97. Falk JH, Koran JJ, Dierking LD, Dreblow L. Predicting Visitor Behavior. Curator Mus J. 2010 Jun 24;28(4):249-58.

98. Falk JH, Dierking LD. Public institutions for personal learning: establishing a research agenda. Washington, D.C; 1995. 143 p.

99. Kelly L. Engaging Museum Visitors in Difficult Topics Through Socio-cultural Learning and Narrative, Ch 10. In: Cameron F, editor. Hot topics, public culture, museums. Newcastle upon Tyne: Cambridge Scholars; 2010. p. 194-210.

100. Pedretti EG. Perspectives on learning through research on critical issues-based science center exhibitions. Sci Educ. 2004;88(S1):S34-47.

101. Avraamidou L, Osborne J. The Role of Narrative in Communicating Science. Int J Sci Educ. 2009 Aug 1;

102. Boerwinkel DJ, Yarden A, Waarlo AJ. Reaching a Consensus on the Definition of Genetic Literacy 
that Is Required from a Twenty-First-Century Citizen. Sci Educ. 2017 Dec 1;26(10):1087-114.

103. Gutwill J, Allen S. Deepening Students' Scientific Inquiry Skills During a Science Museum Field Trip. J Learn Sci. 2012 Jan 1;21:130-81.

104. Petersen A. Biofantasies: genetics and medicine in the print news media. Soc Sci Med 1982. 2001 Apr;52(8):1255-68.

105. Väliverronen E. Popularisers, Interpreters, Advocates, Managers and Critics. Nord Rev. 2001 Feb $1 ; 22$.

106. Hansen A. Tampering with nature: 'nature' and the 'natural' in media coverage of genetics and biotechnology. Media Cult Soc. 2006 Nov 1;28(6):811-34.

107. Pedretti E. T. Kuhn Meets T. Rex: Critical Conversations and New Directions in Science Centres and Science Museums. Stud Sci Educ. 2002 Jan;37(1):1-41. 

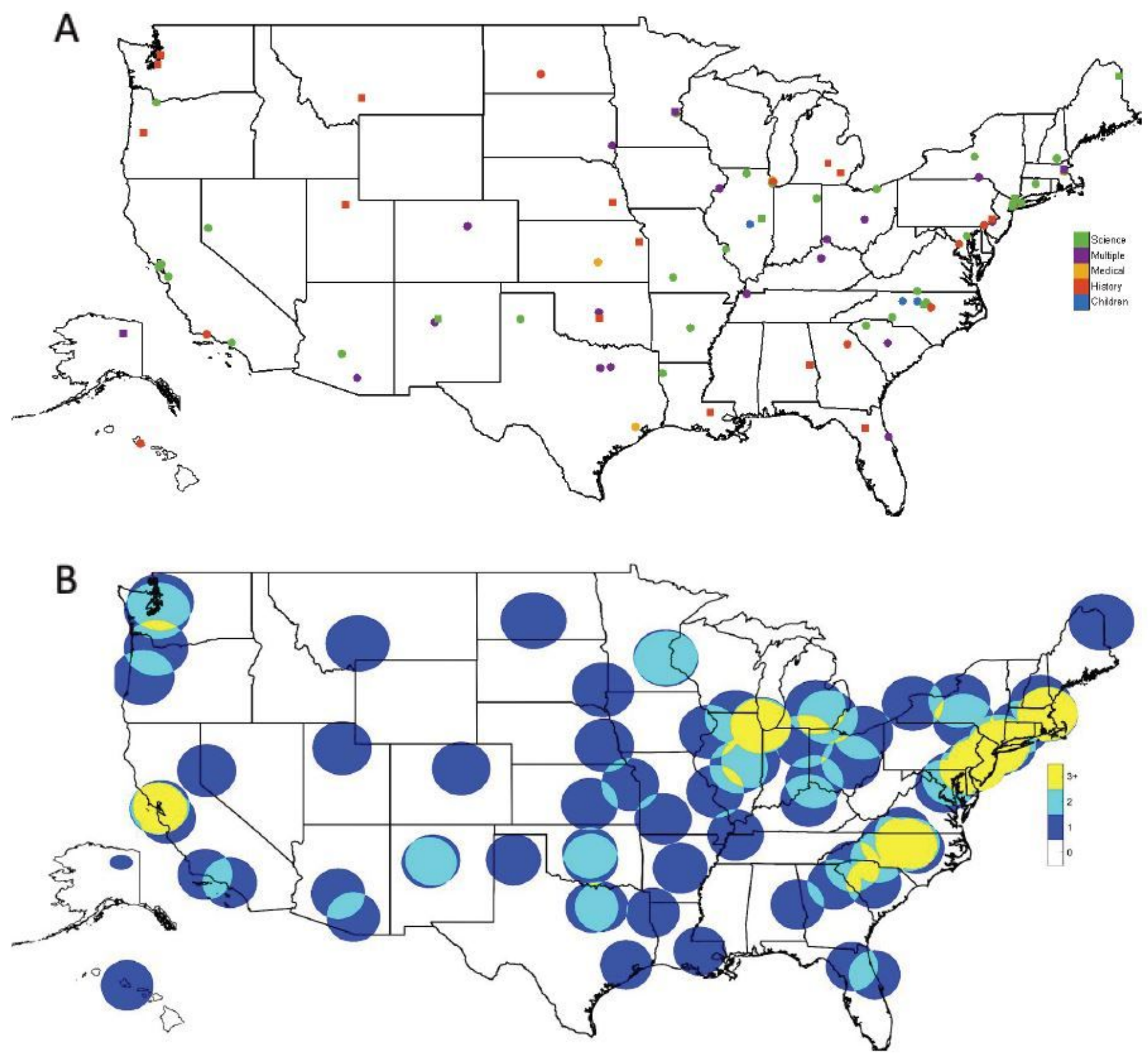

Figure 1

Location of Museums Carrying Genetic Content in the United States . A systematic review of 691 museums across the nation revealed that only 88 museums had exhibits containing genetic content. A) The location of museums carrying genetic content by type: children (blue), history (orange), medical

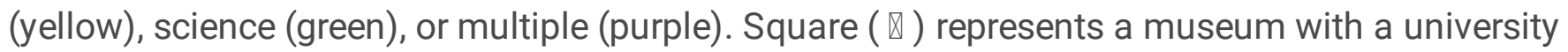
affiliation and circle $(\mathbb{\nabla})$ represents a museum with no university affiliation. B) Areas of the United States with access to genetic content coverage based on a 150-mile radius, where one (blue), two (aqua), or greater than two museums (yellow) were represented. Note: The designations employed and the presentation of the material on this map do not imply the expression of any opinion whatsoever on the 
part of Research Square concerning the legal status of any country, territory, city or area or of its authorities, or concerning the delimitation of its frontiers or boundaries. This map has been provided by the authors.

\section{Supplementary Files}

This is a list of supplementary files associated with this preprint. Click to download.

- HowelletalSupp.Material1MetaAnalysis.xlsx 